\title{
REFORMS OF THE COMMUNITY AGRARIAN POLICY: MISCONCEPTION OR NEW AGRICULTURAL ARCHITECTURE?
}

\author{
Boris Spasojević; Aleksandar Đukić \\ Catering, Trade and Tourism Vocational School, Banja Luka, Bosnia and Herzegovina \\ Dragan Stanković \\ Republic Administration for Geodetic and Property Affairs of Republic of Srpska, Banja Luka, \\ Bosnia and Herzegovina
}

date of paper receipt:

23.10.2017.

Review article date of sending to review:

25.10.2017. date of review receipt:

04.11.2017.

\section{SUMMARY}

The European Union is the most complex and by any aspect the most unique example of a regional economic integration. Its origin, evolution and survival are based on a common legislative and institutional framework. The so-called common policies implemented in a number of economic and non-economic areas are particularly distinctive. Most of them are implemented on two levels: national and communal. The only common policy that is fully implemented at the European Union level is the Community Agrarian Policy (CAP), whereas the agriculture has the highest expenditure in the communal budget. The function of CAP is primarily economic as its goals are strictly related to economic issues: price stability of agricultural products, productivity growth, higher wages for the farmers, etc. The CAP strengthens the Union's social cohesion, which is of utmost importance in times of constant crises, BREXIT and other extreme instabilities. For this reason, the CAP has been in the processes of continuous reforms (MacShary, Mansholt and those of recent times) for decades, in order to increase its efficiency and justify enormous financial investments. The CAP results depend on the achievement of preset objectives and the exchange of agricultural products and food that the European Union generates globally. It has been demonstrated that the CAP is a significant common policy, both in achieving economic goals and in the sphere of strengthening communal cohesion.

Keywords: Community Agrarian Policy, European Union, reforms, goals of the CAP, agriculture.

\section{INTRODUCTION}

Although it has a small share in total GDP in developed countries, agriculture is a strategically important economic sector. For example, in the European Union (EU), agriculture generates about $2 \%$ of GDP, but employment in this branch is higher and accounts for about $4 \%$. Due to such relations, production and employment in agriculture are not equally relevant. Alongside with economic potential, the agricultural population acts both as an important demographic resource and as a compact political factor, much more homogeneous than other social groups. It is precisely because of such values, back in the time of creating the Community that farmers from the founding countries accepted European integrations and because of the promises that they will thereby protect their financial status and ensure development of the agricultural sector and agriculture as a whole in the long term. 
The term „modern agriculture” speaks of a reformed and technologically advanced branch. Developed countries have modern agrarian economies under continuous reforms (Zakić and Stojanović, 2008, pp. 10-15). The first modern reforms were carried out by the United States. In the mid-1950s, the primary agriculture is subject to structural and other reforms, mostly under the pressure of the increasing technical progress. At that time and even today, the United States boast a more efficient agricultural sector than Europe (except for Britain and to some extent France). Although it is the leader in trading agricultural products and food, the productivity of EU agriculture is lagging behind the US. The growth of technical and technological progress improves production. A modern farming sector is unthinkable without business firms working for the sake of production and marketing of agricultural products. Modern agriculture is considered to be more influential than a mere sum of farms, warehouses and intermediaries.

Thus, for example, the American definition of agribusiness perceives the sum of activities related to the production and distribution of agricultural products. According to them, modern agriculture consists of family farms and large companies, food industry, trade, banks and marketing companies, equipment and machinery, catering, etc. Therefore, agriculture does not include only physical and biological production. That is the reason the economic policies deal with this sector, i.e. sectorial measures of the so-called agricultural policy. These measures in the EU mainly include subsidies, pricing policy and protection, as well as other support instruments.

\section{GENESIS AND EVOLUTION OF THE COMMUNITY AGRARIAN POLICY}

Community Agrarian Policy (CAP) is the oldest common, or community policy. Since its creation, there has been a question of supporting this branch. Nowadays, agriculture is an autochthonous, traditional, but also the most controversial policy in the EU. Although its share in the GDP is relatively low, the budget for supporting agriculture is still extremely high. In the period 2007-2013, although being the largest, the budget for agriculture has been slightly reduced, while in the period 2014-2020, it has managed to retain the same level. Today the CAP is fully implemented at the EU level and firmly incorporated into the intra and extrapositions of the Community.

The Treaty of Rome mentions a community agrarian policy, but not the methods of its organization. It only strengthened support for integration. At that time, the EEC members had a significantly higher share of agriculture in GDP and employment (in France, Germany, Italy, the Netherlands and Belgium, its share in GDP was about 10\%, whereas the employment amounted to about 20\%). Later, the Treaty of Amsterdam emphasizes the need for production growth and higher standards, better supply and stable prices. Initial and additional goals evolve from the traditional to modern agriculture, that was initially protected by import duties, barriers and other incentives in the EU. The Summit in Streza (1958) provided contours and principles of the CAP by emphasizing the issues of agricultural development: a unified market and free intra-trade of agricultural products and food without customs duties, taxes, quotas and other restrictions, giving priority to the Community products and financial solidarity of CAP costs. Therefore, a unified market for agricultural products was to be formed with the priority given to domestic products.

The Community Agrarian Policy was de facto launched in 1962 through the cooperation and partnership of agriculture and society, that is, the Union and its farmers. A common goal, with the growth of productivity, was sublimated in safe and affordable food supply and the assumptions for achieving reasonable farmers' earnings.

Later, (in 1964), the Commission proposes to the Council a Community Agrarian Policy, which rapidly gave birth to collecting import duties (levies) and subsidies for most agrarian products, whereas foreign trade moves to a controlled regime of export incentives and high import duties. With minor changes, this system managed to function for almost three decades. It was a period of enormous growth in production and export, but also a year with unwanted surpluses of agricultural 
products and food.

MacShary Reform reforms of CAP (in 1992) were confirmed in the Maastricht Treaty, adding "including rural areas." The accompanying Maastricht document is Delors II Package, in which rural development encourages the stay of landowners on their land, diversifies production, community development planning and environmental protection (European Commission).

Agenda 2000 is the most important document of the Commission following the MacShary Reform (in 1992) on the future of the CAP. It opens new prospects for rural development and affirms economic and social cohesion. The Council of Europe (end of 1997) at the proposal of Jacques Santer adopts AGENDA 2000 as the basis of its reform. The Agenda is a program of strengthening the community policy followed by Structural Funds. It puts emphasis on the living standard of the farmers, competitiveness without high subsidies, as well as environmental protection, quality and product diversification (Barnes and Barnes, 2009).

Reforms have been on the rise, but it should be noted that some changes took place due to the pressure of GATT and the WTO, because in the final rounds, there have always been negotiations on reductions in interventions in agriculture.

The Cork Declaration was adopted at the European Conference on Rural Development, where political directions of further activities in the implementation of rural policy were adopted (Plumb, 1996, p.7-9). It confirmed that citizens of the Union should pay for sustainable growth, higher quality of life and a balanced social situation

Fischler's Reform (1999) foresees that agricultural expenditure may increase up to $74 \%$ of GDP growth. Price reductions in the Berlin Agreement (1999) are not new to the CAP reforms, as the weakening of price support began with the MacSherry Reform (in 1992). Nevertheless, the reduction was not that significant to cause higher level import to occur. Fischler's reform also stimulates specific areas (mountains-hills or the ones featuring severe climatic conditions). The goal of the reforms from Berlin is to adapt the CAP to the eastern extensions. Through amendments, the Council adopts the Berlin Agreement as a compromise, whereby the intervention prices of cereals are reduced by $15 \%$, with increase in direct payments to farmers. However, the reductions in the price of agricultural products in the Berlin Agreement were not new, as it has been stated before, the reduction in incentives for intensive production had already been introduced through MacShary Reforms when farmer incentives were increased, with reduction in price support and direct payments to producers.

Reforms from 2003 introduced income support, whereas subsidies became separated from production. Farmers became eligible for income support, but under the condition to take care of land, animals, environmental standards and product safety.

The continuity of reforms continued in 2008 with the introduction of the so-called health check instruments. The second pillar of the CAP included issues of climate change, environment and biodiversity, as well as the production of renewable energy. The key items of health check strategies include: distinction of payment for production, support for sectors with specific problems, gradually abolishing milk quotas by 2015 and increasing assistance for young farmers.

The new reforms (from 2011) have been aimed at strengthening the competitiveness of the agricultural complex, growth of technical progress and innovation, as well as the prevention of negative effects of climate change and the growth of rural employment. Modern CAP consists of three interactive dimensions: market and income support, and rural development. At that time, 12.2 million farms were registered in the EU, which accounted for 174.1 million hectares of land, or two fifths (about 40\%) of the total area (2010). An average of 14.2 ha of farmland was cultivated (European Commission). In 2012, 10.3 million (full time) workers were registered.

Despite the reduction of the CAP allocations, they are still the largest. From year 2007 to 2013 they were slightly reduced. In the period 2014-2020, there has been a stagnation trend. From 2007 to 2013, CAP funds without rural development were reduced by about $3 \%$, whereas the share of agriculture and rural development in the EU budget decreased from 45\% (2006) to 31\% (2013). 
Deep reforms of the payment system have also been made.

A part of the subsidies was transferred to the "rural economy" due to the circumvention of the WTO rules. In doing so, the EU's relations with the WTO remained undisturbed, whereby the village started developing in a new way. This refers to an indirect support to the village and the strengthening of economic and social cohesion. Thus, it allowed for interventionism to be introduced into the agricultural production and rural economy in a "circumventive" manner.

The new reforms (confirmed by the discussion on the new CAP) emphasise the following: increasing the competitiveness of European agriculture, creating a more just and diversified agrarian system, better attitude towards climate and protecting natural resources, as well as improving relations in the food chain (Mikuš, Franić, Ramani, 2010, pp. 345 -358). At the end of 2013, the European Union published four directives of the new CAP, which include: rural development, horizontal issues such as e.g. financing and control, direct payments and market measures.

The new CAP (after year 2013) is demonstrated in the following figure:

Figure 1. Community Agrarian Policy after 2013 (Agriculture policy and perpectives).

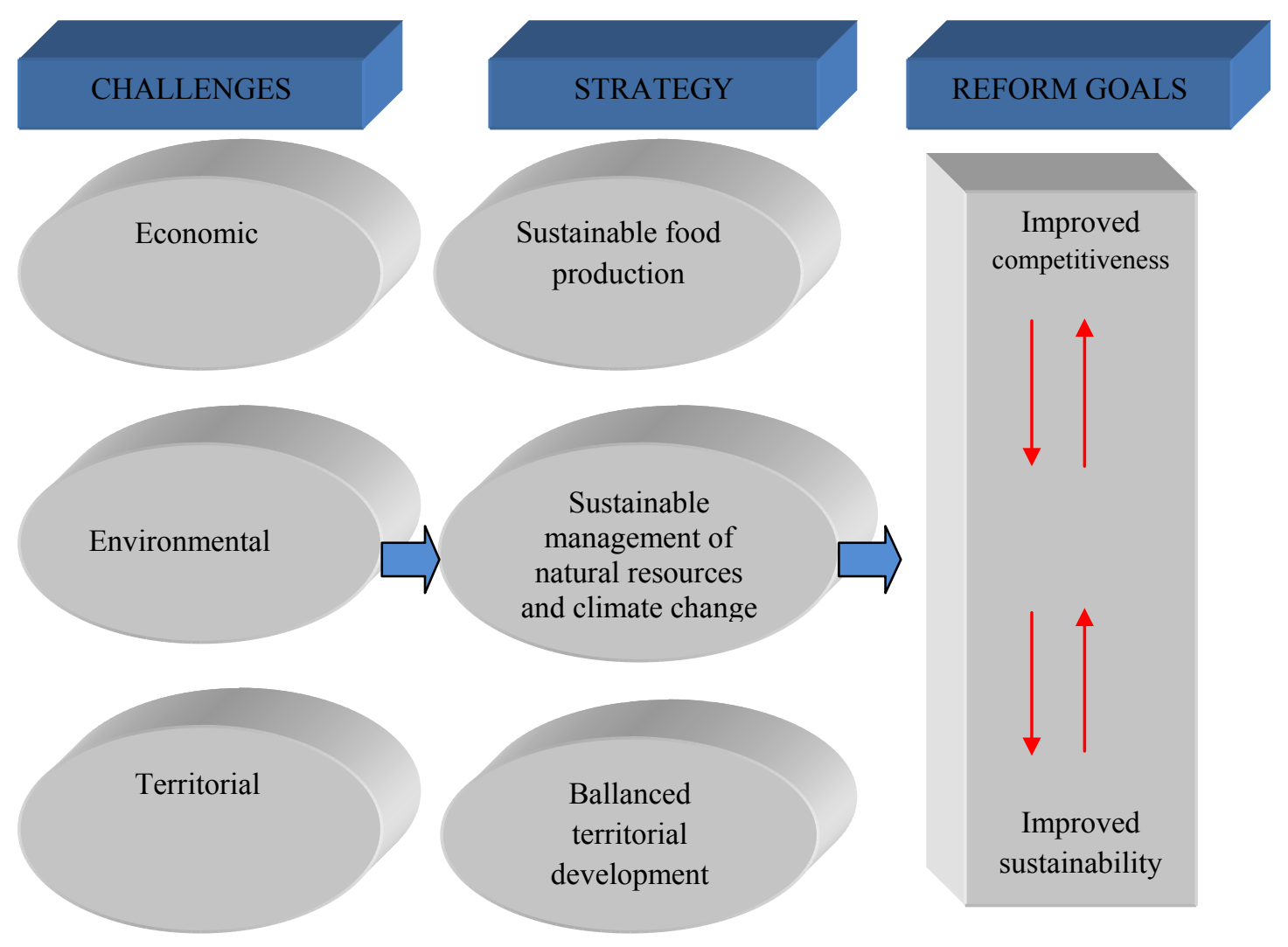


requirements and terms of labelling. It is easier to trade in the intra-market, the information on the origin of goods, varieties, production method and price are much better. Namely, organization of the market is a set of legal regulations for a product on the regulation of production and sales in the euro market (prices, purchase guarantees, sale of food to non-members, etc.). There is a gradual transition (after 2008) from different product categories (21 markets) onto a unique organization of the market for all products.

\section{GOALS, INSTRUMENTS AND RESULTS OF THE EU CAP}

As stated before, the general goals were defined by the Treaty of Rome. By introducing the CAP, the Commission became in charge of proposing measures and goals of the CAP: to supply throughout the Union and stabilize the common market with agricultural products and food at "affordable prices", to increase productivity with the rational use of inputs, stimulate the growth of technical progress, and ultimately ensure the growth of farmers' living standards. The starting goals could be achieved by price policies, stimulations, favourable financing, various barriers, etc.

Nowadays, the Union has a developed system of financing agricultural production. Most of the initial goals have been accomplished, thereby placing the updated goals under the limelight. New goals have been added to the new reforms: strengthening competitiveness, implementing a more just and diversified agrarian system, caring for climate and natural resources, improving relations in the food chain, caring for the quality of the production process and finished products, etc. The European Union in the four directives of the new CAP (2013) emphasizes investments in rural development, financing and control, direct payments and market measures. Price policy is still a precondition for the stability of material and financial balances, and monetary compensations have also been affirmed in the Union.

\section{RESULTS AND CONSEQUENCES OF THE IMPLEMENTATION OF CAP}

The European Union has taken advantage of the past 5-6 decades and has managed to apply protectionist and other measures in agriculture for the purpose to achieve global leadership. Today, the EU produces most of the food products which it has natural preconditions for. The EU meets domestic demand while exporting large quantities as well. By achieving self-sufficiency in agriculture, the EU has managed to meet the primary goal of the CAP. More so because at the time of the formation of the Community, domestic demand was not met. However, nowadays food surpluses have led the EU to become the global leader in trading these products. Its participation in the world trade in agricultural products is high and is continuously increasing. In order to preserve such status, the EU continues to hamper global competition.

In the early stages of the CAP, farmers started introducing new machinery, artificial fertilizers and protective agents. Due to the rapid increase in productivity, there have been cases of unwanted food surpluses. In addition to the above, CAP improved the social status of farmers both directly and through diversifying agriculture. It contributed to building of rural economy and infrastructure. It is considered that the prices of agricultural products and food are "appropriate" to the purchasing power of the Union's inhabitants. In the meanwhile, there are also CAP critics who believe that the prices of agricultural products in the EU are "unfair and inappropriate", especially when compared to the import ones. Table 1 and Table 2 show the trends in prices until the outbreak of the economic crisis. 
Table 1 Agricultural production price indices 2001-2008 $(2000=100)$

\begin{tabular}{|c|c|c|c|c|c|c|c|c|}
\hline GEO/TIME & 2001 & 2002 & 2003 & 2004 & 2005 & 2006 & 2007 & 2008 \\
\hline EU $28(2000=100)$ & 104,6 & 104,8 & 106,5 & 111,6 & 112,6 & 116,1 & 125,9 & 144,4 \\
\hline $\begin{array}{l}\text { EU } 28 \text { (change in } \\
\%)\end{array}$ & 4,6 & 0,2 & 1,6 & 4,7 & 0,9 & 3,1 & 8,4 & 14,7 \\
\hline
\end{tabular}

Source: Eurostat $(2008 ; 2017)$

Table 2 General price index 2001-2008 $(2000=100)$

\begin{tabular}{|c|c|c|c|c|c|c|c|c|}
\hline GEO/TIME & 2001 & 2002 & 2003 & 2004 & 2005 & 2006 & 2007 & 2008 \\
\hline $\mathrm{EU}(2000=100)$ & 101,2 & 103,5 & 105,6 & 107,9 & 110,3 & 112,7 & 115,2 & 119.0 \\
\hline
\end{tabular}

Source: Eurostat $(2008 ; 2017)$

The tables show that in the eight year period, the prices of agricultural products and food grew by about $44 \%$, which is cumulatively about $25 \%$ more than the general price increase. This confirmed the statements of the CAP critics that the prices of agricultural products and foods were too high in relation to the import ones. The highest growth was registered in 2007 and 2008 and is the result of the global price increase of agricultural products that preceded the financial crisis in the United States.

Self-sufficiency and export depended on total agricultural production. Table 3 shows that the growth of agricultural production before the crisis is significant, but it is nevertheless significantly lower than the price growth of these products.

Table 3 Agricultural manufacture indices 2001-2008 $(2000=100)$

\begin{tabular}{|l|r|r|r|r|r|r|r|r|}
\hline GEO/TIME & \multicolumn{1}{|c|}{2001} & \multicolumn{1}{c|}{2002} & \multicolumn{1}{c|}{2003} & \multicolumn{1}{c|}{2004} & 2005 & 2006 & \multicolumn{1}{c|}{2007} & \multicolumn{1}{c|}{2008} \\
\hline EU 27 ( 2000=100 ) & 106,4 & 103,9 & 107,9 & 108,6 & 106,5 & 112,2 & 122,6 & 129,3 \\
\hline EU 27 ( change in \% ) & 6,4 & $-2,3$ & 3,8 & 0,7 & $-2,0$ & 5,4 & 9,3 & 5,5 \\
\hline
\end{tabular}

Source: Eurostat $(2009 ; 2017)$

Production of agricultural products follows increase in GDP and industrial manufacturing, as evidenced in below tables.

Table 4 GDP EU 28 in bn EUR and industrial growth

\begin{tabular}{|c|c|c|c|c|c|c|c|c|c|c|}
\hline GEO/TIME & 2007 & 2008 & 2009 & 2010 & 2011 & 2012 & 2013 & 2014 & 2015 & 2016 \\
\hline EU 28 GDP & 17,834 & 18,116 & 16,459 & 17,653 & 18,516 & 18,919 & 19,021 & 19,675 & 20,721 & 20,887 \\
\hline $\begin{array}{l}\text { Index } \\
2010=100\end{array}$ & 101.9 & 102.4 & 97.9 & 100.0 & 101.7 & 101.2 & 101.5 & 103.3 & 105.6 & 107.6 \\
\hline $\begin{array}{l}\text { Industrial } \\
\text { growth \% }\end{array}$ & 3.7 & -1.8 & -13.8 & 6.7 & 3.2 & -2.1 & -0.5 & 1.2 & 2.3 & 1.4 \\
\hline
\end{tabular}

Source: Eurostat $(2009 ; 2017)$

Table 5 Gross added value in agricultural industry (bn EUR)

\begin{tabular}{|l|l|l|l|l|r|r|r|l|r|l|}
\hline $\begin{array}{l}\text { GEO/ } \\
\text { TIME }\end{array}$ & 2007 & 2008 & 2009 & 2010 & 2011 & 2012 & 2013 & 2014 & 2015 & 2016 \\
\hline EU 28 & 345.971 & 365.481 & 323.550 & 349.441 & 383.559 & 395.476 & 406.511 & 399.992 & 394.112 & 381.038 \\
\hline $\begin{array}{l}\text { Index } \\
2010=100\end{array}$ & 110,5 & 105,6 & 88,5 & 100 & 109,7 & 103,1 & 102,7 & 98,3 & 98,52 & 96,6 \\
\hline
\end{tabular}

Source: Eurostat $(2010 ; 2017)$ 
Table 6 Grain production value (bn EUR)

\begin{tabular}{|c|c|c|c|c|c|c|c|c|c|c|}
\hline GEO/TIME & 2007 & 2008 & 2009 & 2010 & 2011 & 2012 & 2013 & 2014 & 2015 & 2016 \\
\hline EU 28 & 49.997 & 52.666 & 36.095 & 45.413 & 56.160 & 59.662 & 55.762 & 52.908 & 50.438 & 43.455 \\
\hline $\begin{array}{l}\text { Index } \\
2010=100\end{array}$ & 147,3 & 105,3 & 68,5 & 100 & 123,6 & 106,2 & 93,4 & 94,8 & 95,3 & 86,1 \\
\hline
\end{tabular}

Source: Eurostat $(2012 ; 2017)$

The oscillations of GDP growth are more than obvious, but also the stagnation of gross added value in agriculture $(2014,2015,2016)$, as well as in the production of cereals, which are the key agricultural product. The cause is global oscillations and natural factors. Additionally, the gross added value of the food production sector has been dropping slightly since 2014 .

The primary objective of productivity growth is the achievement of other goals: the correct use of inputs and the increase of technical progress in agriculture. Support has long been focused on technically and technologically prolific productions. The result is high yields in certain productions, which can be illustrated by the high growth in wheat yield in the EU founding countries. Labour productivity in the agriculture EU is on the rise, which is also reflected in the gross added value, as can be seen from Table 5. Although there are oscillations, it is obvious that this indicator is growing in the long run.

Graph 1 yield of wheat in the original six Member States (1961-2015)

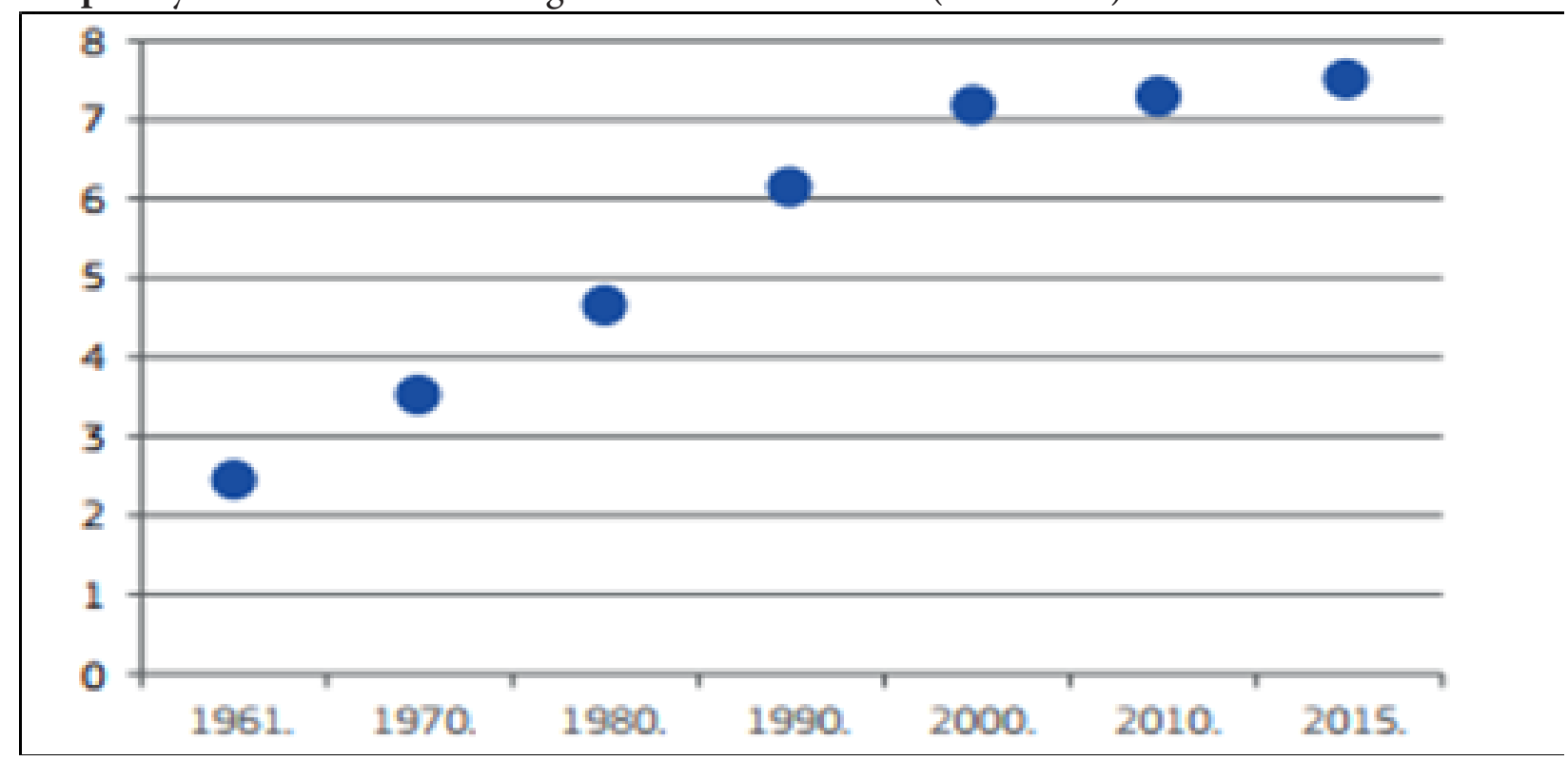

Long-term tendencies in wheat yields for EU founders show growth in productivity. Older member countries nowadays achieve yields of $7 \mathrm{t} / \mathrm{ha}$, which is close to the maximum for the European climate conditions and land quality. Decades of investments in CAP have affected yield growth in other plant and animal production as well.

Finally, by intensifying rural development policy, the European Union effectively implements new policies in agriculture promoted by the new CAP. In this context, the highlights are upon the activities and results focused on strengthening competitiveness, introduction of a more just agrarian system and diversifying agriculture, greater concern for preserving climate and natural renewable and non-renewable resources, as well as improving relations between participants in the food chain. Today, the EU achieves maximum quality of production of primary and finished agricultural products. 


\section{CONCLUSION}

Although significant oscillations of production growth and prices of agrarian products have been observed, there is still a continuity of production levels and relative price stability. Although, higher price fluctuations give the critics the right to state that the prices of agricultural products and food in the EU are too high, the objectives of self-sufficiency and "acceptable" prices have largely been accomplished. However, due to the low income of the poorest population category, the high share of food expenditure in total consumption is registered. After all, it is well known that lower food prices indirectly affect the growth of real wages.

EU participation in global trade of agrarian products is high and continuously keeps growing. Alongside with the US, the EU is the world's leading food exporter that dictates global production standards, quality and even the prices of some products. Its companies are present in all markets.

Interests in this area are heterogeneous, meaning it is natural that the standpoints of the CAP are contradictory. Therefore, the social significance of the CAP's influence on the social sphere is controversial. Nowadays, CAP measures directly affect the social status of farmers and the economic environment in (and around) agriculture. The growth of farm incomes intensified the growth of the rural economy, infrastructure, environmental protection and the improvement of living conditions in the countryside. All of the above affects the development of the food industry.

The use of new production methods in agriculture affects the continuous growth of productivity. The new CAP is three-dimensional and includes market support, income support and support for rural development. These dimensions are interactive. Market support is specific. Income support for direct payments stimulates farm income growth and stimulates organic production. Rural development, as a third dimension, has been intensively implemented within the CAP, as well as within regional policy and other communal measures. The Union successfully implements the CAP measures foreseen by the new reforms. Although it is difficult to accurately determine the effects of centralizing agricultural policy, it can be concluded that European production of agricultural products and food without CAP would be quantitatively and qualitatively at a lower level. Community Agrarian Policy is an important economic and cohesion factor, especially in periods of crisis, economic and geopolitical instability. However, as it has been already pointed out, the views on the CAP are often opposed, meaning that the controversies about the significance and impact of the CAP on the economic, social and cohesion aspects of EU member states do not pose a surprise.. 


\section{LITERATURE}

1. Barnes, P. i Barnes,G.(1999).Environmental policy in the European Union. Edward Elgar Pub, $U K$.

2. European Commission (2000). From the Single Act to Maastricht and Beyond: the Means to mach our Ambitions. Downloaded on 15 October 2017. from https://www.cvce.eu/en/obj/commission_ communication_from_the_single_act_to_maastricht_and_beyond_the_means_to_match_our_ ambitions_11_february_1992-en-ff61d9a6-7b3f-4153-8ba1-451af0476e28.html

3. Mikuš, O., Franić, R. i Ramani, D.(2013). Smjernice zajedničke poljoprivredne politike Europske unije nakon 2013 (eng. Guidelines of the Community Agrarian Policy of the European Union after 2013). Agronomic Gazette, Zagreb.

4. Plumb, H.(1996). The Cork Declaration - A Living Countryside, Rural Europe - Future perspectives. Cork, Ireland.

5. Popović, G. (2016). Ekonomija Evropske unije (eng. Economics of the European Union). Institute for textbooks and teaching aids, East Sarajevo.

6. Popović, G., Zakić, Z. and Stojanović, Ž. (2009). Savremena ruralna politika (eng. Contemporary Rural Politics), Faculty of Economics, University in Banja Luka.

7. Eurostat (2013). Overview of CAP Reform 2014-2020. Downloaded on 15 October 2017 from http://ec.europa.eu/agriculture/policy-perspectives/policy-briefs/05_en.pdf

8. Zakić, Z. and Stojanović, Ž. (2008). Ekonomika agrara (Economics of Agriculture). Faculty of Economics, Belgrade. 